\title{
A STUDY OF FINANCIAL LITERACY AMONG THE PEOPLE OF NORTH EAST INDIA WITH SPECIAL REFERENCE TO MIZORAM
}

\author{
Binod Murmu ${ }^{1}$, Prof. Bhartendu Singh ${ }^{2}$ \\ ${ }^{1}$ Research Scholar, Mizoram University, Mizoram, India \\ ${ }^{2}$ Professor Mizoram University, India
}

Article DOI: https://doi.org/10.36713/epra9570 DOI No: 10.36713/epra9570

\begin{abstract}
Financial literacy is the basic skills, ability and knowledge required to effectively and efficiently manage the personal finance. The study assessed the financial literacy of the 200 respondents of Mizoram and its association with various demographic variables was analysed. The result indicates that majority of the respondents possessed average financial literacy and the very less percentage of the respondents possess poor financial literacy. The findings of the study also show that financial literacy is affected by employment status of the respondents and is not affected by gender, age, income, educational qualification.

KEYWORDS: Financial Knowledge, Financial Behaviour, Financial Attitude, Financial Literacy
\end{abstract}

\section{Introduction}

Financial literacy has become an important research topic in recent years. With the present complex market structure and the availability of different financial products in the market the importance of being financially literate has become more and more important. Financial literacy will help an individual to effectively manage his financial and make an informed choice and investment decision in the market.

Financial Literacy is defined by defined by different organisations, authorities and scholars. Some of the most common definition of financial literacy are quoted below:

- "Financial literacy is the ability to make informed judgements and to take effective decisions regarding the use and management of money. Financial Literacy is therefore a combination of person's skills, knowledge, attitudes and ultimately their behaviours in relation to money." (ANZ Bank, 2011)

- "A combination of awareness, knowledge, skill, attitude and behaviour necessary to make sound financial decisions and ultimately achieve individual financial wellbeing." (OECD INFE, 2012)

Thus, financial literacy is the basic skills, ability and knowledge required for an individual to effectively and efficiently manage his personal finance.

\section{LITERATURE REVIEW}

Hogart and Hilgert (2002) in their study of financial literacy among adults in US shows that respondents who are unmarried, less educated, low income group, young and old, minority possessed less financial knowledge than others.

Mandell and Klein (2009) analyse the differential impact of financial management course on 79 high schools' students. The findings of the study shows that those respondents who took financial management course does not possessed better financial literacy than those who had not taken the course.

Agarwal et. at. (2010) in their study analyse the financial literacy of selected groups who has participated in an online investment service. The result shows that male respondents perform better than female in answering the survey questions and also the increase in the educational level of the respondents increase the level of aggressiveness of investment. The study also shows that respondents are financially literate.

Agarwalla et al (2012) in their study among 3000 respondents shows less than $1 / 4$ of the respondents have good financial knowledge. 
Bhushan \& Medury (2013) in their study found that financial literacy gets affected by demographic characteristics like education, gender, income, nature of employment and place of work. Futher, the result also shows that high financial literacy is found among the respondents with higher income.

Gupta and Kinange (2016) in his study among 60 respondents found that financial literacy level is very low among the respondents and the study also finds that financial literacy has no impact on the level of satisfaction of the bank employees.

\section{RESEARCH METHODOLOGY}

\section{A. Objectives of the Study}

1. The main objective of the study is to assess the financial literacy level of the respondents.

2. To study the association between socio-economic profile and financial literacy level of the respondents

\section{B. Sample Size}

The sample size consists of 200 respondents from Aizawl and random sampling was used to collect the data.

\section{Data Collection}

Questionnaire framed by OECD-INFE (2011) was used to collect primary data in which questions on financial knowledge, financial behaviour, financial attitude, financial awareness and preference of the respondents were asked.

Secondary data are collected from books, journals, internet etc.

\section{Scoring procedure for financial literacy}

Financial Literacy score for an individual is determined by taking a weighted average of Financial Knowledge score, Financial Behaviour score and Financial Attitude score. Weights used are: 50 per cent for Financial Knowledge, 30 per cent for Financial Behaviour and 20 per cent for Financial Attitude. Aggregate score of 1 to 3 was designated as Poor Level of Financial Literacy, score 4 and 5 as Average level of financial literacy and score 6 and above as high level of financial literacy.

\section{RESULTS AND DISCUSSIONS}

\section{Key Socio-economic Profile}

The key socio-economic information of the respondents consists of their gender, age, number of family members, educational qualification and annual family income.

Table 1: Gender

\begin{tabular}{|l|c|c|}
\hline & Frequency & Percent \\
\hline Male & 111 & $55.5 \%$ \\
\hline Female & 89 & $44.4 \%$ \\
\hline Total & 200 & $100 \%$ \\
\hline
\end{tabular}

Sample Survey

Table 1 indicates the gender wise classification of the respondents. The result shows that among the respondents 55.5 per cent respondents are male and the rest 44.4 per cent are female.

Table 2: Age

\begin{tabular}{|l|c|c|}
\hline & Frequency & Percent \\
\hline Upto 30 & 40 & $20 \%$ \\
\hline Between 31-40 & 56 & $28 \%$ \\
\hline Between 41-50 & 52 & $26 \%$ \\
\hline Between 51-60 & 45 & $22.5 \%$ \\
\hline Above 60 & 7 & $3.5 \%$ \\
\hline Total & 200 & $100 \%$ \\
\hline
\end{tabular}

Sample Survey

Table 2 shows the age wise classification of the respondents. The result shows that 20 per cent of the respondents belongs to the age group of upto 30, 28 per cent of the respondents belongs to the age group of between 31-40, 26 per cent belongs to the age group of between 41-50, 22.5 per cent belongs to the age group of between 5160 and 3.5 per cent belongs to the age group of above 60 . 
Table 3: No. of Family members

\begin{tabular}{|l|c|c|}
\hline & Frequency & Percent \\
\hline $2-4$ & 60 & $30 \%$ \\
\hline $5-7$ & 115 & $57.5 \%$ \\
\hline Above 7 & 25 & $12.5 \%$ \\
\hline Total & 200 & $100 \%$ \\
\hline
\end{tabular}

Sample Survey

From the above table 3 it has been observed that 30 per cent of the respondents belongs to the categories of 2-4 family members, 57.5 per cent belongs to the categories of 5-7 family members and 12.5 per cent belongs to the categories of above 7 family members.

Table 4: Educational Qualification

\begin{tabular}{|l|c|c|}
\hline & Frequency & Percent \\
\hline 10 th & 55 & $27.5 \%$ \\
\hline 12 th & 57 & $28.5 \%$ \\
\hline Graduation & 65 & $32.5 \%$ \\
\hline Post-Graduation & 23 & $11.5 \%$ \\
\hline Total & 200 & $100 \%$ \\
\hline
\end{tabular}

Sample Survey

Table 4 shows educational qualification of the respondents. From the total respondents, 27.5 per cent are $10^{\text {th }}$ passed, 28.5 per cent are $12^{\text {th }}$ passed, 32.5 per cent are graduate and 11.5 per cent are post-graduate.

Table 5: Annual family income

\begin{tabular}{|l|c|c|}
\hline & Frequency & Percent \\
\hline 3-4 lakhs & 132 & $66 \%$ \\
\hline 4-5 lakhs & 34 & $17 \%$ \\
\hline 5-6 lakhs & 16 & $8 \%$ \\
\hline Above 5 lakhs & 18 & $9 \%$ \\
\hline Total & 200 & 100 \\
\hline
\end{tabular}

Sample Survey

Table 5 determines the annual income of the respondents. From the total respondents, majority 66 per cent have an income of 3-4 lakhs, 17 per cent have an income of 4-5 lakhs, 8 per cent have an income of 5-6 lakhs and 9 per cent have an income of above 5 lakhs.

Table 6: Employment

\begin{tabular}{|l|c|c|}
\hline & Frequency & Percent \\
\hline Govt. & 126 & $63 \%$ \\
\hline Non-Govt. & 27 & $13.5 \%$ \\
\hline Self-Employed & 47 & $23.5 \%$ \\
\hline Total & 200 & $100 \%$ \\
\hline
\end{tabular}

Sample Survey

Table 6 determines the employment status of the respondents. From the total population, majority 63 per cent are government employees, 13.5 per cent are non-government employees and 23.5 per cent are self-employed.

\section{Financial Literacy}

\begin{tabular}{|c|l|c|c|c|c|}
\multicolumn{2}{|c|}{} & \multicolumn{4}{|c|}{ Table 7: Gender and Financial Literacy } \\
\cline { 3 - 6 } \multicolumn{2}{|c|}{} & $\begin{array}{c}\text { Foor Financial } \\
\text { Literacy }\end{array}$ & $\begin{array}{c}\text { Average } \\
\text { Financial } \\
\text { Literacy }\end{array}$ & $\begin{array}{c}\text { Good Financial } \\
\text { Literacy }\end{array}$ & \multirow{2}{*}{ Total } \\
\hline \multirow{2}{*}{ Male } & Frequency & 0 & 64 & 47 & 111 \\
\cline { 2 - 6 } & Percent & $0.00 \%$ & $57.70 \%$ & $42.30 \%$ & $100.00 \%$ \\
\hline \multirow{2}{*}{ Female } & Frequency & 3 & 50 & 36 & 89 \\
\cline { 2 - 6 } & Percent & $3.40 \%$ & $56.20 \%$ & $40.40 \%$ & $100.00 \%$ \\
\hline \multirow{2}{*}{ Total } & Frequency & 3 & 114 & 83 & 200 \\
\cline { 2 - 6 } & Percent & $1.50 \%$ & $57.00 \%$ & $41.50 \%$ & $100.00 \%$ \\
\hline
\end{tabular}

Sample Survey 
Table 7 shows the financial literacy level of the respondents based on their gender. The result shows that male respondents possessed slightly higher percentage of good and average financial literacy level. And only 3.40 per cent of the female respondents possessed poor financial literacy. The overall result shows that not much difference was found between financial literacy of male and female respondents.

Table 8: Age and Financial Literacy

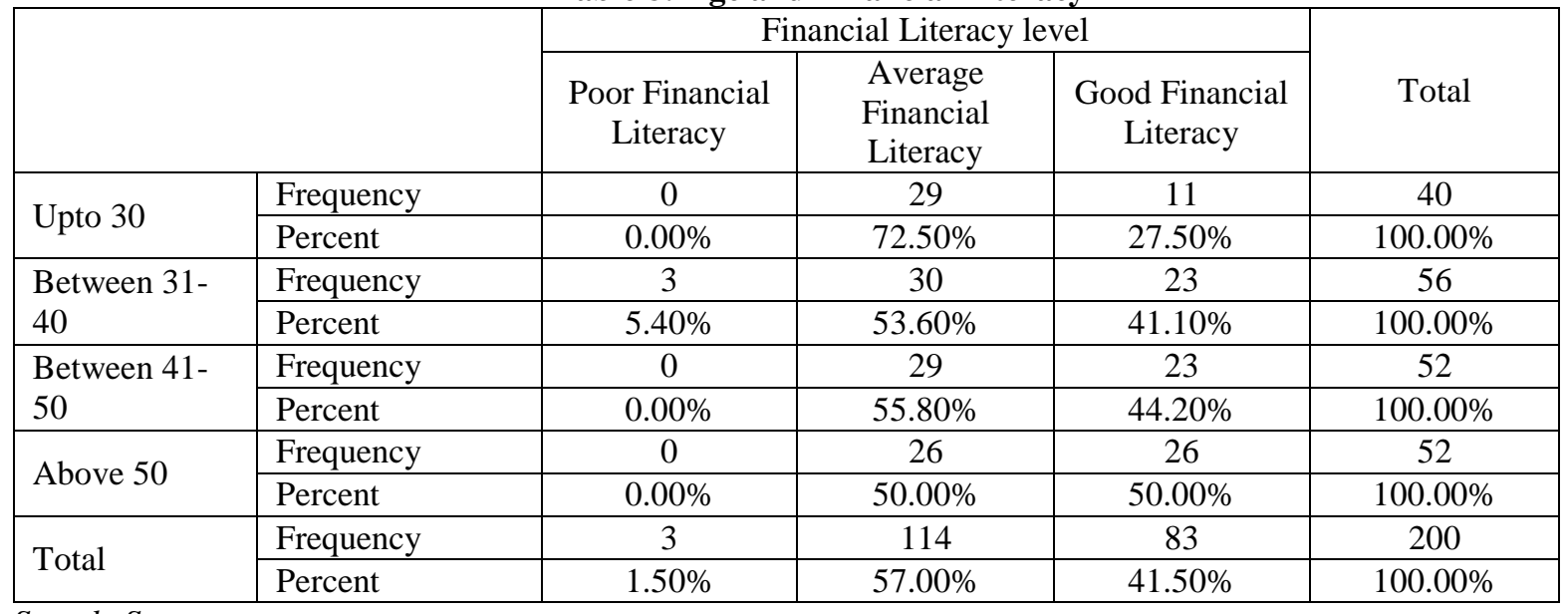

\section{Sample Survey}

Table 8 represent financial literacy level of the respondents on the basis of their age. The result shows that in the categories of good financial literacy the highest percentage of good financial literacy is possessed by age group of above 50 (50 per cent) and the least is among the age group of upto 30 years ( 27.50 per cent). More than 50 per cent of all the age group possessed average financial literacy and poor financial literacy is possessed by only age group of between 31-40 years (5.40 per cent). It is evident from the result that there is a positive relationship between age and financial literacy of the respondents.

Table 9: No. of Family Members and Financial Literacy

\begin{tabular}{|c|l|c|c|c|c|}
\hline \multicolumn{2}{|c|}{} & \multicolumn{3}{|c|}{ Financial Literacy level } & \multirow{2}{*}{ Total } \\
\cline { 3 - 6 } \multicolumn{2}{|c|}{} & $\begin{array}{c}\text { Poor Financial } \\
\text { Literacy }\end{array}$ & $\begin{array}{c}\text { Average } \\
\text { Financial } \\
\text { Literacy }\end{array}$ & $\begin{array}{c}\text { Good Financial } \\
\text { Literacy }\end{array}$ & \\
\hline \multirow{2}{*}{$2-4$} & Frequency & 3 & 31 & 26 & 60 \\
\cline { 2 - 6 } & Percent & $5.00 \%$ & $51.70 \%$ & $43.30 \%$ & $100.00 \%$ \\
\hline \multirow{2}{*}{$5-7$} & Frequency & 0 & 68 & 47 & 115 \\
\cline { 2 - 6 } & Percent & $0.00 \%$ & $59.10 \%$ & $40.90 \%$ & $100.00 \%$ \\
\hline \multirow{2}{*}{ Above 7 } & Frequency & 0 & 15 & 10 & 25 \\
\cline { 2 - 6 } & Percent & $0.00 \%$ & $60.00 \%$ & $40.00 \%$ & $100.00 \%$ \\
\cline { 2 - 6 } Total & Frequency & 3 & 114 & 83 & 200 \\
\cline { 2 - 6 } & Percent & $1.50 \%$ & $57.00 \%$ & $41.50 \%$ & $100.00 \%$ \\
\hline
\end{tabular}

\section{Sample Survey}

Table 9 represents financial literacy of the respondents on the basis of no. of family members. The result shows that in the good financial literacy category the percentage of good financial literacy decreases with the increase in family members. The highest percentage of good financial literacy was possessed by family members between 2-4 (43.30 per cent) and the least was among the family members of above 7 (40 per cent). Majority of the respondents possessed average financial literacy and only 5.3 per cent of the family members between 2-4 possessed poor financial literacy.

Table 10: Educational Qualification and Financial Literacy

\begin{tabular}{|l|l|c|c|c|c|}
\hline \multicolumn{2}{|c|}{} & \multicolumn{3}{|c|}{ Financial Literacy level } & \multirow{2}{*}{ Total } \\
\cline { 3 - 6 } \multicolumn{2}{|c|}{} & $\begin{array}{c}\text { Poor Financial } \\
\text { Literacy }\end{array}$ & $\begin{array}{c}\text { Average } \\
\text { Financial } \\
\text { Literacy }\end{array}$ & $\begin{array}{c}\text { Good Financial } \\
\text { Literacy }\end{array}$ & \\
\hline \multirow{2}{*}{ Upto 10th } & Frequency & 0 & 36 & 19 & 55 \\
\cline { 2 - 6 } & Percent & $0.00 \%$ & $65.50 \%$ & $34.50 \%$ & $100.00 \%$ \\
\hline \multirow{2}{*}{12 th } & Frequency & 3 & 34 & 20 & 57 \\
\cline { 2 - 6 } & Percent & $5.30 \%$ & $59.60 \%$ & $35.10 \%$ & $100.00 \%$ \\
\hline Graduation & Frequency & 0 & 33 & 32 & 65 \\
\hline
\end{tabular}




\begin{tabular}{|l|l|c|c|c|c|} 
& Percent & $0.00 \%$ & $50.80 \%$ & $49.20 \%$ & $100.00 \%$ \\
\hline \multirow{2}{*}{ Post-Graduation } & Frequency & 0 & 11 & 12 & 23 \\
\cline { 2 - 6 } & Percent & $0.00 \%$ & $47.80 \%$ & $52.20 \%$ & $100.00 \%$ \\
\hline \multirow{2}{*}{ Total } & Frequency & 3 & 114 & 83 & 200 \\
\cline { 2 - 6 } & Percent & $1.50 \%$ & $57.00 \%$ & $41.50 \%$ & $100.00 \%$ \\
\hline
\end{tabular}

\section{Sample Survey}

Table 10 represents financial literacy level of the respondents on the basis of their educational qualification. The percentage of good financial literacy is highest among the post graduate (52.20 per cent) and is lowest among the respondents who are $10^{\text {th }}$ passed category (34.50 per cent). Except for post graduate respondents, more than 50 per cent of all the categories possessed average financial literacy. And only 5.30 per cent of the $12^{\text {th }}$ passed possessed poor financial literacy. The overall result shows that financial literacy level increases with increase in the educational qualification of the respondents.

Table 11: Annual Income and Financial Literacy

\begin{tabular}{|l|l|c|c|c|c|}
\hline \multicolumn{2}{|c|}{} & \multicolumn{3}{|c|}{} & \multirow{2}{*}{ Financial Literacy level } \\
\cline { 3 - 6 } \multicolumn{2}{|c|}{} & $\begin{array}{c}\text { Poor Financial } \\
\text { Literacy }\end{array}$ & $\begin{array}{c}\text { Average } \\
\text { Financial } \\
\text { Literacy }\end{array}$ & $\begin{array}{c}\text { Good Financial } \\
\text { Literacy }\end{array}$ & \\
\hline \multirow{2}{*}{$3-4$ lakhs } & Frequency & 3 & 77 & 52 & 132 \\
\cline { 2 - 6 } & Percent & $2.30 \%$ & $58.30 \%$ & $39.40 \%$ & $100.00 \%$ \\
\hline \multirow{2}{*}{$4-5$ lakhs } & Frequency & 0 & 19 & 15 & 34 \\
\cline { 2 - 6 } & Percent & $0.00 \%$ & $55.90 \%$ & $44.10 \%$ & $100.00 \%$ \\
\hline \multirow{2}{*}{$5-6$ lakhs } & Frequency & 0 & 8 & 8 & 16 \\
\cline { 2 - 6 } & Percent & $0.00 \%$ & $50.00 \%$ & $50.00 \%$ & $100.00 \%$ \\
\hline \multirow{2}{*}{$\begin{array}{l}\text { Above 6 } \\
\text { lakhs }\end{array}$} & Frequency & 0 & 10 & 8 & 18 \\
\hline \multirow{2}{*}{ Total } & Percent & $0.00 \%$ & $55.60 \%$ & $44.40 \%$ & $100.00 \%$ \\
\cline { 2 - 6 } & Frequency & 3 & 114 & 83 & 200 \\
\hline
\end{tabular}

Sample Survey

Table 11 represents financial literacy of the respondents with relation to their age. The table shows that the percentage of Good financial literacy is highest among the income categories of 5-6 lakhs (50 per cent) and in lowest among the income categories of 3-4 lakhs (39.40 per cent). Which shows that the level of good financial literacy increases with the increase in income level of the respondents. More than 50 per cent of all the income categories possessed average financial literacy and only 2.30 per cent of the 3-4 lakhs income category possess poor financial literacy.

Table 12: Employment and Financial Literacy

\begin{tabular}{|l|l|c|c|c|c|}
\hline \multicolumn{2}{|c|}{} & \multicolumn{2}{|c|}{ Financial Literacy level } & \multirow{2}{*}{ Total } \\
\cline { 3 - 6 } \multicolumn{2}{|c|}{} & $\begin{array}{c}\text { Poor Financial } \\
\text { Literacy }\end{array}$ & $\begin{array}{c}\text { Average } \\
\text { Financial } \\
\text { Literacy }\end{array}$ & $\begin{array}{c}\text { Good } \\
\text { Financial } \\
\text { Literacy }\end{array}$ & \\
\hline \multirow{2}{*}{ Govt. } & Frequency & 0 & 71 & 55 & 126 \\
\cline { 2 - 6 } & Percent & $0.00 \%$ & $56.30 \%$ & $43.70 \%$ & $100.00 \%$ \\
\hline \multirow{2}{*}{ Non-Govt. } & Frequency & 3 & 13 & 11 & 27 \\
\cline { 2 - 6 } \multirow{2}{*}{ Self-Employed } & Percent & $11.10 \%$ & $48.10 \%$ & $40.70 \%$ & $100.00 \%$ \\
\cline { 2 - 6 } & Frequency & 0 & 30 & 17 & 47 \\
\hline \multirow{2}{*}{ Total } & Percent & $0.00 \%$ & $63.80 \%$ & $36.20 \%$ & $100.00 \%$ \\
\cline { 2 - 6 } & Frequency & 3 & 114 & 83 & 200 \\
\hline
\end{tabular}

Sample Survey

Table 12 determines the financial literacy of the respondents in relation to their employment status. The result shows that the government employees ( 43.70 per cent) possess the highest percentage of good financial literacy followed by non-government employees (40.70 per cent) and self-employed (36.20 per cent). It is evident from the result that average financial literacy is possessed by more than 50 per cent of all the three categories except the nongovernment employees who possessed close to it i.e. 48.1 per cent. No respondents form the government and selfemployed possessed poor financial literacy.

\section{Hypotheses}

$\mathrm{H}_{01}$ There is no association between Gender and Financial Literacy level 
Table 13: Fisher's Exact Test on Association between Gender and Financial Literacy

\begin{tabular}{|l|c|c|c|c|}
\hline & Value & df & $\begin{array}{c}\text { Asymp. Sig. } \\
\text { (2-sided) }\end{array}$ & $\begin{array}{c}\text { Exact Sig. } \\
(2 \text {-sided) }\end{array}$ \\
\hline Pearson Chi-Square & $3.803^{\mathrm{c}}$ & 2 & 0.149 & 0.179 \\
\hline Likelihood Ratio & 4.92 & 2 & 0.085 & 0.154 \\
\hline Fisher's Exact Test & 3.381 & & & 0.179 \\
\hline Linear-by-Linear Association & $.504^{\mathrm{d}}$ & 1 & 0.478 & 0.497 \\
\hline N of Valid Cases & 200 & & & \\
\hline
\end{tabular}

Fisher's Exact test significance value is 0.179 . Since the significance value is greater than 0.05 null hypothesis is accepted. Hence, there is no association between gender and financial literacy level of the respondents. The result is inconsistent with the findings of Job Joseph (2012)

$\mathrm{H}_{02}$ There is no association between Age and Financial Literacy level

Table 14: Fisher's Exact Test on Association between Age and Financial Literacy

\begin{tabular}{|l|c|c|c|c|}
\hline & Value & df & $\begin{array}{c}\text { Asymp. Sig. } \\
\text { (2-sided) }\end{array}$ & $\begin{array}{c}\text { Exact Sig. } \\
(2 \text {-sided })\end{array}$ \\
\hline Pearson Chi-Square & $12.867^{\mathrm{c}}$ & 6 & 0.045 & 0.037 \\
\hline Likelihood Ratio & 12.877 & 6 & 0.045 & 0.041 \\
\hline Fisher's Exact Test & 9.541 & & & 0.078 \\
\hline Linear-by-Linear Association & $4.905^{\mathrm{d}}$ & 1 & 0.027 & 0.027 \\
\hline N of Valid Cases & 200 & & & \\
\hline
\end{tabular}

Fisher's Exact test significance value is 0.078 . Since the significance value is greater than 0.05 , the null hypothesis is accepted. Hence, there is no association between age and financial literacy level among the respondents. The finding is in consistent with the previous research by Gloria (2014)

$\mathrm{H}_{03}$ There is no association between No. of family members and Financial Literacy level

Table 15: Fisher's Exact Test on Association between No. of Family Members and Financial Literacy

\begin{tabular}{|l|c|c|c|c|}
\hline & Value & df & $\begin{array}{c}\text { Asymp. Sig. } \\
\text { (2-sided) }\end{array}$ & $\begin{array}{c}\text { Exact Sig. } \\
(2 \text {-sided) }\end{array}$ \\
\hline Pearson Chi-Square & $7.504^{\mathrm{c}}$ & 4 & 0.112 & 0.118 \\
\hline Likelihood Ratio & 7.735 & 4 & 0.102 & 0.112 \\
\hline Fisher's Exact Test & 5.712 & & & 0.182 \\
\hline Linear-by-Linear Association & $.047^{\mathrm{d}}$ & 1 & 0.829 & 0.914 \\
\hline N of Valid Cases & 200 & & & \\
\hline
\end{tabular}

Fisher's Exact test significance value is 0.182 . Since the significance value is greater than 0.05 the null hypothesis is accepted. Hence, there is no association between number of family members and financial literacy level of the respondents.

$\mathrm{H}_{04}$ There is no association between Educational qualification and Financial Literacy level

Table 16: Fisher's Exact Test on Association between Educational qualification and Financial Literacy

\begin{tabular}{|l|r|r|r|r|}
\hline & Value & df & \multicolumn{1}{|c|}{$\begin{array}{c}\text { Asymp. Sig. } \\
\text { (2-sided) }\end{array}$} & $\begin{array}{c}\text { Exact Sig. } \\
(2 \text {-sided) }\end{array}$ \\
\hline Pearson Chi-Square & $11.842^{\mathrm{c}}$ & 6 & 0.066 & 0.060 \\
\hline Likelihood Ratio & 11.820 & 6 & 0.066 & 0.063 \\
\hline Fisher's Exact Test & 8.832 & & & 0.114 \\
\hline Linear-by-Linear Association & $4.001^{\mathrm{d}}$ & 1 & & 0.45 \\
\hline N of Valid Cases & 200 & & & \\
\hline
\end{tabular}

Fisher's Exact test significance value is 0.114 . Since the significance value is greater than 0.05 the null hypothesis is accepted. Hence, there is no association between educational qualification and financial literacy level of the respondents. The finding is contrast with the findings of Gloria (2014), Job Joseph (2012) 
$\mathrm{H}_{05}$ There is no association between Income and Financial Literacy level

Table 17: Fisher's Exact Test on Association between Income and Financial Literacy

\begin{tabular}{|l|r|r|r|r|}
\hline & \multicolumn{1}{|l|}{ Value } & df & \multicolumn{1}{c|}{$\begin{array}{c}\text { Asymp. Sig. } \\
\text { (2-sided) }\end{array}$} & $\begin{array}{c}\text { Exact Sig. } \\
(2 \text {-sided })\end{array}$ \\
\hline Pearson Chi-Square & $2.252^{\mathrm{c}}$ & 6 & 0.895 & 0.911 \\
\hline Likelihood Ratio & 3.188 & 6 & 0.785 & 0.862 \\
\hline Fisher's Exact Test & 1.686 & & & 0.953 \\
\hline Linear-by-Linear Association & $.961^{\mathrm{d}}$ & 1 & & 0.327 \\
\hline N of Valid Cases & 200 & & & \\
\hline
\end{tabular}

Fisher's Exact test significance value is 0.953 . Since the significance value is greater than 0.05 the null hypothesis is accepted. Hence, there is no association between income qualification and financial literacy level of the respondents. The result is in consistent with the findings of Gloria (2014)

$\mathrm{H}_{06}$ There is no association between Employment and Financial Literacy level Table 18: Fisher's Exact Test on Association between Employment and Financial Literacy

\begin{tabular}{|l|r|r|r|r|}
\hline & Value & df & \multicolumn{1}{|c|}{$\begin{array}{c}\text { Asymp. Sig. } \\
\text { (2-sided) }\end{array}$} & $\begin{array}{c}\text { Exact Sig. } \\
(2 \text {-sided })\end{array}$ \\
\hline Pearson Chi-Square & $20.453^{\mathrm{c}}$ & 4 & 0.000 & 0.002 \\
\hline Likelihood Ratio & 13.265 & 4 & 0.010 & 0.009 \\
\hline Fisher's Exact Test & 11.167 & & & 0.014 \\
\hline Linear-by-Linear Association & $1.065^{\mathrm{d}}$ & 1 & 0.302 & 0.334 \\
\hline N of Valid Cases & 200 & & & \\
\hline
\end{tabular}

Fisher's Exact test significance value is 0.014 . Since the significance value is less than 0.05 the null hypothesis is rejected. Hence, there is a significant association between employment status and financial literacy level of the respondents. The result is in consistent with the findings of Gloria (2014).

\section{FINDINGS}

- The overall assessment of financial literacy level of the respondents shows that majority i.e. 57 per cent of the respondents possessed average financial literacy and 41.5 per cent of the respondents possessed good financial literacy.

- Gender wise analysis of financial literacy among the respondents shows that male respondents slightly possessed higher percentage of good financial literacy than female respondents.

- Age wise analysis of financial literacy of the respondents shows that age group of above 50 possessed the highest percentage of positive financial literacy. Further the result also shows that financial literacy increases with the increase in age of the respondents.

- Number of family members between 2-4 possessed the highest percentage of positive financial literacy and the least percentage was among the family members of above 7 . The percentage of positive financial literacy has an inverse relationship the number of family members

- Education wise analysis of financial literacy of the respondents shows that the percentage of good financial literacy increases with the increase in education level of the respondents. The highest percentage of positive financial attitude was among the post graduates.

- Income wise analysis shows that, the percentage of positive financial literacy is lowest among the income group of 3-4 lakhs and highest among the income grou

- Self-employed has the lowest percentage of good financial literacy whereas government employees have the highest percentage

- Fisher's Exact Test was conducted to find the association between financial literacy and sociodemographic profile of the respondents, The result shows that gender, age, income, education, number of family members have no association with the financial literacy level fo the respondents whereas significant association was found between employment and financial literacy level of the respondents.

\section{CONCLUSION}

The study examines the financial literacy of the respondents of Mizoram and the result shows that the financial literacy level is moderate. Fisher's exact test was used to analyzed the association between financial literacy and socio-demographic profile of the respondents. The result shows that gender, age, income, education, 
number of family members have no association with the financial literacy level of the respondents whereas significant association was found between employment and financial literacy level of the respondents

\section{REFERENCES}

1. Agarwal, S., Gene, A., Ben, I. D, Souphala, C\&Evanoff, D. D. (2010), 'Financial Counseling, Financial Literacy, and household Decision Making.’ Pension Research Counsel Working Paper, 2010-34.

2. Atkinson, A. and Messy, F-A, (2011), 'Assessing financial literacy in 12 countries: an OECD/INFE international pilot exercise', Journal of Pension Economics and Finance, Vol 10, issue 4, pp. 657-665.

3. Agarwalla, S.K., Barua, S., Jacob, J. \& Varma, J.R. (2012), 'A Survey of Financial Literacy among Students, Young Employees and the Retired in India'. Extracted on $29^{\text {th }}$ November, 2013 from http://www.iimahd.ernet.in/fls/fls12/Executive_Summary.pdf

4. Bhushan, P., \& Medury, Y. (2013),. 'Financial Literacy and its Determinants.' International Journal of Engineering, Business and Enterprise Applications, Vol. 4(2), pp. 155-160. Retrieved from http://iasir.net/IJEBEApapers/ IJEBEA13-145.pdf

5. Desdemona A. C.M. (2018), 'Relevance for Demographic Factor: Level of financial literacy' SCMS Journal of Indian Management, January- March 2018 Volume XV Number 1 pp.68-77

6. Gupta, P.K and Kinange, U.M (2016), 'A Study of Financial Literacy and its Impact on Consumer Satisfaction with Special Reference to Banks of Bagalkot District.' International Journal of Management (IJM) Volume 7, Issue 6, September-October 2016, pp.43-50

7. Gloria, J.T.M. (2014). Assessment of Financial Literacy for Financial Inclusion Among Low Income Households (Unpublished doctoral dissertation). Avinashilingam Institute of Home Science and Higher Education for Women, Coimbatore (Kerala), India

8. Hogart, J.M., and Hilgert, M.A (2002), 'Financal Knowledge, Experience and Learning Preferences: Preliminary results from a new survey on Financial Literacy.' Consumer Interests Annual, Vol. 48, pp. 1-7.

9. Joseph, J. (2012). Financial Literacy of Economically Marginalised People of Kerala (Unpublished doctoral dissertation). Mahatma Gandhi University, Kottayam (Kerala), India

10. Mandell, L. and Klein, L.S (2009), 'The Impact of Financial Literacy Education on Subsequent Financial Behavior.' Journal of Financial Counseling and Planning, Vol. 20, No. 1, 2009, Available at SSRN: https://ssrn.com/abstract $=2224231$

11. Organisation for Economic Co-operation and Development (OECD) (2005), Improving financial literacy: Analysis of issues and policies. Extracted on March, 2014 from http://titania. sourceoecd.org/vl=4607980/cl=25/nw=1/rpsv/ij/oecdthemes $/ 9998007 x / \mathrm{v} 2005 \mathrm{n} 30 / \mathrm{s} 1 / \mathrm{p} 11$.

12. PACFL, USA (2008), President's Advisory Council on Financial Literacy, 2008 Annual Report to the President. Available: https://www.treasury.gov/about/organizational-structure/offices/DomesticFinance/Documents/PACFL_Draft-AR-0109.pdf 